\title{
Policies for Sustainable Agriculture and Livelihood in Marginal Lands: A Review
}

\author{
Hayatullah Ahmadzai ${ }^{1, *(\mathbb{D})}$, Seta Tutundjian ${ }^{1}$ and Ismahane Elouafi ${ }^{2}$ \\ 1 International Center for Biosaline Agriculture, Dubai P.O. Box 14660, United Arab Emirates; \\ s.tutundjian@biosaline.org.ae \\ 2 Food and Agriculture Organization of the United Nations, 00153 Rome, Italy; ismahane.elouafi@fao.org \\ * Correspondence: h.ahmadzai@biosaline.org.ae; Tel.: +971-50-4017937
}

Citation: Ahmadzai, H.; Tutundjian, S.; Elouafi, I. Policies for Sustainable Agriculture and Livelihood in Marginal Lands: A Review. Sustainability 2021, 13, 8692. https:// doi.org/10.3390/su13168692

Academic Editor: Piotr Prus

Received: 7 June 2021

Accepted: 9 July 2021

Published: 4 August 2021

Publisher's Note: MDPI stays neutral with regard to jurisdictional claims in published maps and institutional affiliations.

Copyright: (c) 2021 by the authors. Licensee MDPI, Basel, Switzerland. This article is an open access article distributed under the terms and conditions of the Creative Commons Attribution (CC BY) license (https:// creativecommons.org/licenses/by/ $4.0 /)$.

\begin{abstract}
Despite the substantial improvements in agricultural productivity owing to technological progress, the poor in agriculturally marginal areas are overlooked and left behind. Nearly a billion people still live in poverty, the majority of whom happen to be in developing countries, with a larger share of those who are poor living on marginal lands. Food insecurity is a vicious reality in the everyday lives of these marginalized poor, and the threat of food insecurity and hunger is becoming even more serious and imminent, with increasing trends in population growth. Climate change is expected to add yet more weight to this equation and to pose greater risks for the livelihoods of these communities. In spite of the challenges faced, addressing marginal agriculture systems and poverty is vital to achieving the Sustainable Development Goals (SDGs). In this paper, we investigate the historical policy perspective towards marginal areas to pinpoint potential shortcomings in the policy environment. Subsequently, we present a roadmap to future research engagement and develop a policy framework, with instruments and strategies focusing on the food-poverty-environment nexus, to target poverty reduction, preserve biodiversity, and restore marginal lands. Our analysis of historical policies reveals that conventional policy approaches towards marginal agriculture have been conducive to favorable areas (specific to input-responsive crops only), neglecting marginal areas. Future policies to address the food-poverty-environment nexus within marginal environments must evolve around a framework that is all-inclusive but context-specific. Agricultural and other public investments should be prioritized geographically in accordance with the characteristics of marginality hotspots. Policy instruments should encourage long-term solutions to enhance productivity through regenerative production systems and preserve the environmental resource base.
\end{abstract}

Keywords: agricultural marginality; sustainable production; historical policies; research engagement; policy outlook

\section{Introduction}

Current land and agricultural systems are driven by intensive farming systems and their variations, with a set of outcome-based practices such as improving productivity, enhancing resource-use efficiency, and mitigating environmental impacts [1]. However, it has been argued that sustainable intensification strategies are not focusing on all three dimensions of sustainability, especially the social and ecological aspects. That is, the intensification strategy has limitations in terms of balancing productivity and long-term sustainability. Moreover, sustainable intensification promotes producing more food from the same area of land, precluding the expansion of land [1,2]. Given current agricultural trends and the growing human population, more land must be cultivated to meet food demand and the global goal of food security [3].

To ensure food and ecological security, land and agriculture systems will require a transformation from sustainable intensification towards a regenerative and self-sustaining approach [4]. To this end, regenerative agricultural systems driven by agro-ecological principles and processes are becoming an increasingly acceptable development pathway 
with a clear set of economic, social, agronomical, and environmental objectives [1]. The supporting theory behind regenerative farming practices is to self-sustain the resources that producers use, rather than exhausting and depleting them. The dynamics of structural transformation entails a change to agricultural systems and patterns of land and other resource use [5]. Marginal lands with diverse agroecosystems and vast biodiversity can play an important role in the scope and dynamism of structural transformation by absorbing increased populations, contributing to ground biomass and the food security of the marginalized poor, and preserving the natural resource base through the integration of diverse agro-ecological and topographical characteristics that are typical of marginal areas with intensive agricultural practices $[4,6]$.

Technological progress throughout the Green Revolution (GR) and the decades that followed has sparked economic growth through agricultural productivity. As a result, global poverty has substantially declined [3,7]. However, a large body of research in recent decades has documented that conventional research methods and agricultural technologies targeting favored agricultural areas with high agricultural potential have not adequately addressed the needs of the world's poor farmers in marginal areas where poverty still remains deep-rooted $[8,9]$. Today, a significant share of the world poor, nearly a fifth of the world's population, live on less-favored fragile marginal environments, are prone to poverty, and lag behind in terms of income, health, and overall well-being [10].

Empirical evidence suggests that populations living on less-favored agricultural lands (i.e., lands characterized by constrained agricultural potential due to low productivity and resource degradation) in developing countries cope with major poverty-environment traps [11]. Poverty traps occur because productivity under marginal conditions on remote and less-favored lands is low, while lack of access to markets and infrastructure constraints further undermine profitability and restrict off-farm employment opportunities [12]. The marginal poor are caught in a vicious downward spiral as they overuse environmental resources to survive and meet their day-to-day food demand. The impoverishment of their environmental resources further deprives them, making their survival ever more uncertain and difficult [13].

Conventional theories arguing that marginal areas are characterized by limited agricultural potential, where development efforts are less effective, have led to bias in policymaking against marginal areas. However, numerous researchers have established that marginality is not a static and permanent condition and marginal lands are subject to change in land use, agricultural technologies, and the socio-economic environment [14]. Several interrelated facets could turn productive agricultural lands to marginal or even unproductive land and vice versa. Investments in technologies and the application of proper management practices and tools could reverse this situation; that is, with intensive research engagement and an enabling policy environment, unproductive and marginal lands could be transformed into productive or favored agricultural lands [15-17]. Marginal areas offer territorial advantages and present an opportunity for alternative models of development. The diverse and heterogenous conditions typical of marginal areas may well represent a comparative advantage [18] that could be utilized for the benefit of the extreme poor, who have been overlooked and left behind for decades. A fresh policy outlook, therefore, should recognize and turn such spatial diversity and territorial capital into strength. Research and development (R\&D) and public policies towards these marginal lands need to be revised to target marginal producers, especially the extreme poor, to provide them with incentives to maintain and improve the natural resource base for production without further degradation of resources.

Sustainable Development Goals (SDGs) One and Two call for eradicating extreme poverty and global hunger. Progress in reaching the poorest and most marginalized has been slow, and income inequality continues to increase [19]. The three most recent State of Global Food Security reports [20-22] show that after a steady decline in the number of hungry people, hunger is on the rise again. Further, while the number of the extreme poor fell in East Asia, the Pacific, and South Asia, it has substantially increased in Latin America 
and particularly in Sub-Saharan Africa [23]. Expected future gains in food productivity in marginal areas are important because it is unlikely that food production in mainstream environments will be adequate to meet projected growth in food demand for a global population that is predicted to reach 10 billion by 2050 [3,24,25], particularly with prevailing climate change and biodiversity loss [24].

To meet growing food demand, about a billion hectares of additional cropland are required [3,25]. The expected growth in terms of global food demand is $1.1 \%$ per year from 2005-2007 to 2050, which implies a 56\% increase over the period [3,7]. To match the predicted $1.1 \%$ annual growth in global food demand, global food production in 2050 would need to be approximately 60\% higher than in 2005-2007 [3]. It would be prudent to have crop yields increase around $1.2-1.3 \%$ per year, with a $10 \%$ increase in the area cropped, which will likely deliver around a 45\% increase in staples over 2010 yields [26]. Demographic pressures will add to the challenge of achieving global food security, especially with the critical threats of climate change, water scarcity, and the depletion of soil resources. This is particularly so in marginal environments, where food production is significantly lower due to various biophysical and socio-economic factors [23]. Against this backdrop, we first review historical policy perspectives on marginal areas specifically, to identify and pinpoint potential shortcomings in the policy environment. Ultimately, we present a roadmap for future research engagement and poverty-environment-focused policy frameworks for overcoming the pervasive problems of poverty and food insecurity. This should restore marginal environments by preserving biodiversity and avoiding further degradation of natural resources in agriculturally marginal areas. The contribution of this paper is twofold. First, we synthesize and analyze existing evidence to understand marginality in the context of agriculture. Second, we present concrete policy options and recommendations to encourage agriculture production and food security in marginal areas which have been overlooked by conventional policies.

\section{Marginality in the Context of Agriculture}

The term 'marginal' was originally used under the umbrella of economic theorizing to describe an area under given conditions where cost-effective production is not remunerated [27]. Since then, different definitions describing the concept of marginality and marginal environments have emerged, highlighting the complex nature of marginality and how various unfavorable conditions disadvantage individuals and communities living in these areas $[28,29]$. In the context of the agricultural economy, the term "margins of cultivation" is used to describe economically marginal agricultural lands where revenue from optimal production just equals (or is lower than, in some instances) the costs of production, leading to zero (negative) profit or economic loss [27]. To capture this specific economic context, FAO and UNEP [30] have classified land supporting a yield of only up to 40 percent of its productivity potential as marginal. Marginal lands are also identified as areas where "cost-effective production is not possible under given conditions, cultivation techniques, agriculture policies, and macro-economic and legal settings" [31]. In this context, economically marginal land can be thought of as land that would not be cultivated at current output and input prices without the availability of government support programs [32]. Marginal lands are mostly abandoned, as they are disadvantaged due to factors such as changing commodity markets, international competition, or the demographics of land owners and farm operators [33].

The concept and definition of marginal land varies according to the aim for which the term is used and the given contextual background against which it is operationally applied [17]. Understanding the combination of agroclimatic potential and socio-economic setting provides a working definition of areas that are favored or less-favored for an agricultural purpose, at least for market-oriented production [34]. Less-favored agricultural lands refer to lands that are susceptible to low productivity and resource degradation because their agricultural potential is constrained biophysically by terrain, poor soil quality, salinity, or limited rainfall. The socio-economic dimension of marginality involves several 
aspects, including lack of access to markets and infrastructure, which cause expected economic and social wellbeing to lag behind.

Less-favored agricultural areas (LFAAs) include all less-favored agricultural lands plus any favorable agricultural land (e.g., not constrained by biophysical factors) that is remote or in rural areas with limited access to infrastructure and markets [12]. In other words, LFAAs include agricultural lands that are constrained by limited access to rural agricultural and market infrastructures, even though they might not be constrained by biophysical factors. Although multiple interlinked factors drive marginality, biophysical and socio-economic aspects are the two central dimensions in the context of agriculture, driving agricultural policy and economic welfare. Accordingly, in this paper we argue that LFAAs indicated by the shaded boxes (A, B, C) in Figure 1 could be equated to agriculturally marginal areas. The definition of agricultural marginality is summarized in the paragraph in the following Box 1.

\begin{tabular}{|c|c|c|c|}
\hline \multirow{2}{*}{\multicolumn{2}{|c|}{$\begin{array}{l}\text { Sources/factors } \\
\text { contributing to } \\
\text { marginality }\end{array}$}} & \multicolumn{2}{|c|}{$\begin{array}{l}\text { Socio-economic dimension (i.e., access to } \\
\text { infrastructure and markets, public } \\
\text { service, etc.) }\end{array}$} \\
\hline & & No/limited access & Improved access \\
\hline \multirow{2}{*}{$\begin{array}{l}\text { Agricultural } \\
\text { potential } \\
\text { based on } \\
\text { biophysical } \\
\text { and } \\
\text { environmen } \\
\text { tal factors }\end{array}$} & 3 & $\begin{array}{l}\text { A. Less-favored } \\
\text { fragile and remote } \\
\text { areas: water-scarce, } \\
\text { steep slope, poor } \\
\text { and degraded soils }\end{array}$ & $\begin{array}{l}\text { B. Less-favored } \\
\text { agricultural area: } \\
\text { areas in arid and } \\
\text { semi-arid regions }\end{array}$ \\
\hline & 点 & $\begin{array}{l}\text { C. Less-favored } \\
\text { agricultural areas: } \\
\text { remote areas with } \\
\text { high degree of plant } \\
\text { biodiversity, rich } \\
\text { biotic environment }\end{array}$ & $\begin{array}{l}\text { D. Favorable } \\
\text { agricultural area }\end{array}$ \\
\hline
\end{tabular}

Figure 1. Characterization of agricultural areas based on biophysical and socioeconomic dimensions of marginality. Source: Adopted and modified from $[12,18]$.

Box 1. Definition of agriculturally marginal areas.

Agriculturally marginal areas refer to the less-favorable agricultural areas (LFAAs) characterized by resource degradation, constrained agriculture potential, and low productivity of agricultural resources attributable to biophysical constraints such as rugged terrain, extreme weather conditions, poor soil quality, salinization, drought and erratic rainfall, and other factors that present significant constraints for intensive agriculture. Marginal areas also encompass all LFAAs and any favorable agricultural areas (e.g., areas not constrained by biophysical factors) with limited access to rural infrastructure and agricultural markets where cost-effective production is likely unfeasible (without additional support) under given conditions, cultivation techniques, and policy or macro-economic settings.

\section{Geographical and Regional Identification of Marginal Lands}

The literature offers different statistics on the extent and prevalence of marginal areas, as different studies employ different methods, assumptions, and criteria to estimate the extent of global marginal lands. Marginal lands account for about 36 percent of global agri- 
cultural land (1.3 billion ha), and support roughly one-third of the world's population [35]. Worldwatch Institute [36] estimate that the extent of marginal lands ranges anywhere between 100 million and 1 billion hectares. The estimated global area of abandoned agriculture is 385-472 million hectares [37]. Among the first studies to determine the extent of marginal lands and the distribution of the rural poor on less-favored marginal lands globally was the comprehensive study carried out by the Technical Advisory Committee (TAC) of the Consultative Group on International Agricultural Research (CGIAR), covering 105 developing countries across four regions. According to the CGIAR/TAC report [38], "favored" agricultural lands accounted for only 10.7 percent of agricultural area in the developing world compared with $24 \%$ of marginal agricultural lands.

The Food and Agriculture Organization (FAO) of the United Nations, with the collaboration of The International Institute for Applied Systems Analysis (IIASA), developed a system that enables rational land-use planning on the basis of an inventory of land resources and an evaluation of the biophysical limitations and production potentials of land. This is referred to as the Agro-Ecological Zones (AEZ) methodology [39,40]. GAEZ modelling uses detailed agronomic-based information to simulate land resource availability, assess farm-level management options, and estimate crop production potentials. It employs detailed spatial, biophysical, and socio-economic datasets to distribute its computations at fine-gridded intervals over the entire globe [3,41]. The GAEZ methodology combines soil, terrain, and climate characteristics with crop production requirements, and estimates the suitability in terms of land extent and attainable yield levels. Crop production was assessed at each land grid cell at the 5-arc-minute level at four technology and management levels (low, intermediate, high, and mixed).

Based on the GAEZ suitability assessments, global land resources (excluding Antarctica) comprise 13.15 billion ha (Table 1), of which $46 \%$ is classified as not suitable for production (i.e., characterized by less than $5 \%$ attainable yield potential) and about a fifth of the total land or $21 \%$ ( 2.7 billion ha) is classified as marginal land, with various degrees of suitability for production, including marginally suitable and very marginally suitable, based on attainable yield potential. Out of the 1.6 billion hectares (ha) that are currently in agricultural use, about 225 million ha (nearly 15\%) are classified as marginal.

Table 1. Availability and classification of global land resources.

\begin{tabular}{|c|c|c|c|c|c|c|c|c|c|}
\hline & VS & $S$ & MS & $\mathrm{mS}$ & $\mathrm{vmS}$ & NS & Total & $\begin{array}{l}\text { Potential (VS } \\
+\mathrm{S}+\mathrm{MS})\end{array}$ & $\begin{array}{c}\text { Potential } \\
(\mathrm{mS}+\mathrm{vmS})\end{array}$ \\
\hline $\begin{array}{l}\text { Total land (in } \\
\text { million ha) }\end{array}$ & 1315 & 2187 & 993 & 1111 & 1627 & 6061 & 13,294 & 4495 & 2738 \\
\hline in $\%$ & $10 \%$ & $16 \%$ & $7 \%$ & $8 \%$ & $12 \%$ & $46 \%$ & & $34 \%$ & $21 \%$ \\
\hline $\begin{array}{c}\text { In agricultural } \\
\text { use }(1999 / 2001)\end{array}$ & 442 & 616 & 201 & 120 & 104 & 75 & 1558 & 1260 & 224 \\
\hline of which rainfed & 381 & 516 & 166 & 93 & 84 & 43 & 1283 & 1063 & 177 \\
\hline of which irrigated & 61 & 100 & 35 & 27 & 20 & 32 & 275 & 197 & 47 \\
\hline Gross balance & 873 & 1571 & 792 & 991 & 1523 & & & 3235 & 2514 \\
\hline Under forest & 453 & 854 & 293 & 342 & 530 & 1263 & 3735 & 1601 & 872 \\
\hline Strictly protected & 30 & 50 & 27 & 39 & 59 & 432 & 637 & 107 & 98 \\
\hline Built-up land & 41 & 61 & 14 & 12 & 10 & 15 & 153 & 116 & 22 \\
\hline Net balance & 349 & 606 & 458 & 598 & 924 & & & 1412 & 1522 \\
\hline
\end{tabular}

Notes: Suitability classes are defined according to attainable yields as a percentage of the maximum constraint-free yield as follows: VS = Very Suitable (80-100\% potential) S = Suitable, 60-80\% (yield potential), MS = Moderately Suitable $40-60 \%$ (yield potential), $\mathrm{mS}=$ marginally Suitable $20-40 \%$ (yield potential), vmS = very marginally Suitable 5-20\% (yield potential), NS = Not Suitable < 5\% (yield potential). Prime land = VS; Good land = S + MS; and Marginal land $=\mathrm{mS}+\mathrm{vmS}$. Crops considered in the suitability analysis: cereals, roots and tubers, sugar crops, pulses, and oil-bearing crops. Source: adopted from Alexandratos et al. and Fischer et al. [3,41].

To illustrate the spatial dimensions of marginality at continental and regional levels, Graw and Husmann [42] mapped marginality as a "multidimensional" concept using a set of indicators developed by Grung and Kollmair [14] that alone or together may determine marginal areas or lead to marginality. Graw and Husmann's [42] work utilized national and sub-national data published by the World Bank, the Food and Agriculture 
Organization of the United Nations (FAO), Harvest Choice, and others. For each dimension, a cut-off point along with a range of indicator values were used to define the threshold below which an area could be considered marginal. Indicator layers for each of the different dimensions of marginality were overlaid to find the areas where multiple layers of marginality overlap. Subsequently, a 'marginality hotspot' was defined as an area in which at least three dimensions of marginality overlapped. As evident from Figure 2, major hotspot areas were identified in South Asia (11\% of land area) and Sub-Saharan Africa (nearly $27 \%$ of land area), especially Central and Eastern Africa (Eritrea, Mozambique, Central African Republic, the Democratic Republic of the Congo, Sudan, and large areas of Niger). About $1 \%$ of the total Sub-Saharan Africa area suffered five overlapping dimensions of marginality.

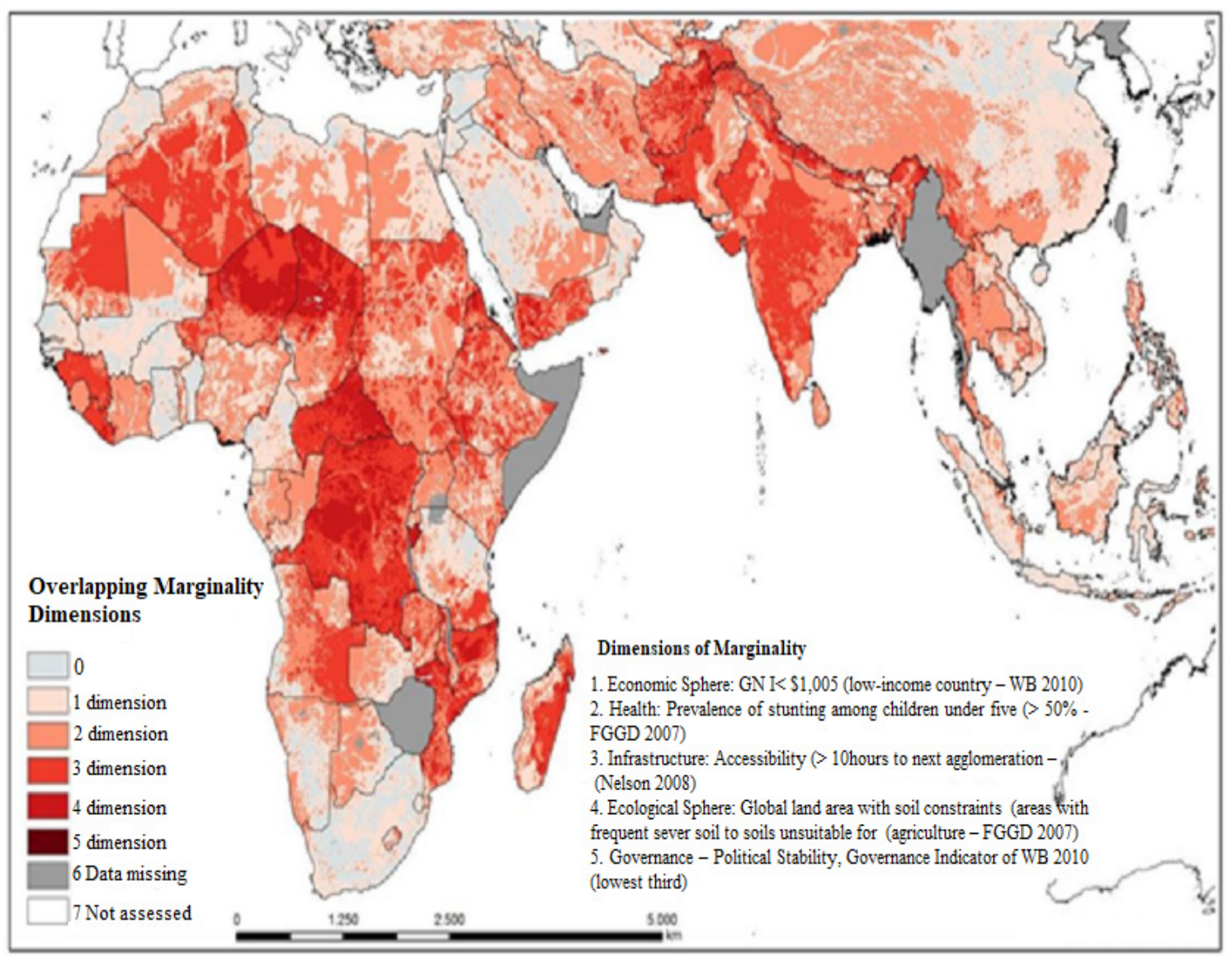

Figure 2. Marginality hotspots—overlapping dimensions of marginality. Source: Reprinted from [42] with permission from [Valarie Graw].

Based on the CGIAR/TAC report [38], nearly two-thirds of rural populations (almost 1.8 million people) lived on less-favored marginal lands, which included marginal agricultural lands, forest and woodland areas, and arid zones. Of these, $36 \%$ are already extremely poor. By 2010, as many as 1.75 billion people worldwide (about $38 \%$ of the rural population) lived on remote, less-favored agricultural areas, up from 1.56 billion people in 2002. This can be largely attributed to the $13.4 \%$ growth in global population between 2002 and 2010 . Nearly all (1.6 out of 1.75 billion) people in marginal areas live in developing countries.

From a poverty-elimination perspective, hotspots representing extremely marginal areas (i.e., areas with five overlapping dimensions of marginality) should be prioritized for research and development programs, followed by relatively less marginal areas (i.e., hotspots representing moderately marginal areas, with two overlapping dimensions) to effectively contribute to achieving the SDG goals for poverty and hunger. However, from a food-production perspective, extremely unsuitable areas may not be the first choice, as 
production capacity is constrained by a limited resource base and harsh climatic factors. Hence, recognizing these aspects will require further research to guide future policy interventions targeting the food-poverty-environment nexus.

\section{Historical Policy Perspective}

Historical research has documented a controversial debate on the merit and prioritization of investments in better-endowed and high-potential agricultural areas as opposed to fragile and marginal production systems with relatively restricted agricultural potential. One normative position in the literature relies on the conventional wisdom that poverty reduction, the overriding goal in rural areas, is most effectively brought about through investments in high-potential favored areas as returns to investment would be greatest in these areas. That is, increased food production and rapid economic growth in favored areas would arguably ensure the overall food security and allow the marginalized poor to migrate out of less-favored areas, ultimately reducing poverty and pressure on the resources in marginal areas [43]. Other researchers presented contradicting arguments stating that while out-migration and economic diversification should become increasingly important in the development of low-potential marginal areas, agricultural intensification will often offer the only viable way of raising incomes and creating employment on the scale required in the near future [44].

Further arguments in support of investing in high-potential areas points to evidence that suggests that well-established factor and output market linkages could lead to reduced poverty in marginal areas because of spillovers of supportive policies in agro-ecologically favorable regions. That is, the increase in wages and the reduction in food prices from these policies are not limited to areas in which investments are undertaken. Instead, spillover effects would ultimately expand to less-favored areas, thus positively affecting incomes and the food security of the poor [43]. Others argue that while growth in the agricultural sector has been highlighted as a fundamental step in reducing poverty in marginal areas, agriculture is volatile to climate shocks under marginal conditions and alternative livelihood options should be explored to ensure environmental and economic sustainability in marginal areas [45].

From the outset of the Green Revolution, the conventional policy approach towards marginal agriculture has been conducive to favorable areas (specific to input-responsive crops only), neglecting marginal areas. Perhaps a major constraint limiting the ability of marginal-land farmers to improve yields and the sustainability of their agricultural systems under resource-poor conditions is the lack of affordable and low-input technology [46]. The vast majority of agricultural research and development for developing countries has been geared toward developing Green Revolution high-yielding crops, varieties that are not suitable for marginal lands. Because the Green Revolution strategy was based on the intensification of favorable areas, its contribution to poverty reduction was rather lacking in marginal production environments [44,46]. As a result, marginal areas have been overlooked, and the extreme poor didn't benefit as much from such technological progress [14]. Only 1\% of African grain fields had been planted with modern varieties of wheat and rice. This could mean that the Green Revolution missed or never made it to Africa. Subsequently, the argument put forward was that the failure of modern varieties to diffuse into such agro-climates resulted in greater regional inequality, particularly when farmers faced lower prices resulting from the increased output in modern-variety-adopting areas. This line of argument has resulted in a significant shift in research attention toward marginal areas [47].

Conventional policies are broadly challenged, and the counter argument is that orthodox approaches leave untouched the concerns that populations in less-favored marginal areas are rapidly increasing, and that the incidence of poverty remains dramatically higher in low-potential areas. Wealth distribution is neither intuitive nor logical, so if we aim to improve livelihoods in marginal environments we are unlikely to achieve it through investing in favorable environments. The general assertion of the benefits of tilting agricul- 
tural and other investments to a country's agro-ecologically better-off regions is countered by the proposition that, over time, returns to public investments in high-potential areas may decline-in other words, further improvements in agricultural productivity in agroecologically favored areas can only be achieved at a large cost, after there is a relative saturation of high-potential areas [43]. Strategies with a focus on highly endowed agroecological areas are no longer viable, as many of the high-potential areas are suffering from various forms of environmental stresses such as salinization and waterlogging of irrigated lands, fertilizer and chemical contaminations of water, and soil erosion, which, together with tapering or perhaps declining yield-potential casts serious doubt on the ability of these areas to continue to meet the growing demand for food on a sustainable basis [48].

Given the bias in historical policies towards agriculturally marginal areas, sustainable development in marginal areas still remains a long-term investment challenge. The arguments and counterarguments presented here result in no conclusive answers to policy questions about how agricultural and other public investments should be prioritized geographically. Further empirical research evidence is required to assess poverty-reducing impacts of the public investments, especially in the agricultural sector [43]. However, considering the trends in population growth and food demand coupled with increasing biophysical stresses on natural resources in prime lands in the face of climate change, major breakthroughs in productivity-enhancing agricultural technologies are essential to reverse resource degradation and put marginal lands to optimal use. This is especially vital in the context of Sub-Saharan Africa, where the share of high-potential prime and irrigated lands are much lower to begin with [48]. Unlike the Green Revolution, these breakthroughs have to build on improved environmental and natural resource management practices.

The overall take-away from this overview of literature on historical policy perspectives towards marginal areas is that these areas have been overlooked and left behind. From the outset of the Green Revolution, the seemingly limited agricultural potential; poorly developed infrastructure, especially imperfect or failing market conditions; and, most importantly, the absence of an economic environment to support profitable investment opportunities have led to bias in policymaking against marginal areas. In retrospect, an important reason for the failure of development interventions in marginal areas has been insufficient knowledge and recognition of the wide variation and heterogeneity in biophysical and socio-economic conditions as prime characteristics of livelihoods and farming systems. Equally, rural households in these areas are diverse in terms of resources, activities, and access to markets and institutions. As a result, various development routes, defined as common patterns of change in livelihood strategies, are not likely to create a successful business environment under marginal conditions [49].

\section{Research and Development and Policy Agenda}

Global agriculture will seemingly face daunting challenges over the decades to come. On the one hand, there is a need to produce more food for a growing and increasingly wealthy population that demands a more diverse diet. On the other hand, in many developing countries with larger share of rural poor, agriculture must also play a dual role and contribute to economic growth, rural employment, and poverty alleviation. On top of this, agricultural systems will face increased competition for scarce natural resources, such as land and water, while helping to preserve biodiversity and restore fragile environments. Ultimately, these resource-poor farmers will have to play a crucial role in mitigating climate change shocks whilst also adapting to increased biophysical stresses including extreme weather events such as droughts, soil degradation and salinity, and heatwaves, all of which threaten global food security.

Despite the substantial drop in the incidence of poverty globally, $10 \%$ or 734 million people are still considered poor, subsisting below USD 1.90 a day. The progress in achieving the overarching goal of poverty reduction has been largely uneven. Most favored areas significantly benefited from the technological progress, but the rural poor, especially those in marginal areas, benefited the least and in some regions the number of poor has even 
increased. Most researchers agree that typology of poverty is explicitly linked to environment, with marginal areas representing the highest concentration of extreme poverty. Agriculture is strategically the backbone of the economies in these marginal areas, but the productivity of agriculture is undermined by several biophysical and socio-economic constraints, making marginal lands more fragile and difficult for policymakers to make successful investments in. Expected future gains in food productivity in marginal areas are important because it is unlikely that increased productivity in favorable environments will be sufficient to meet projected growth in food demand for the global population that is likely to reach 10 billion by 2050 [3,24,25], particularly with prevailing climate change and biodiversity loss.

Despite the challenges faced by the marginalized poor, marginality is a temporary and dynamic concept. Each region has the potential to overcome perceived marginality and the negative consequences of marginality can serve as the starting point of innovations and potential [14]. For instance, an area might be marginal, or less favored for use in crop production under a specific production system, due to water scarcity or lack of market access, but by introducing new water-saving technologies or new marketing routes, this same area could become more favorable [50] or transformed from unproductive (unused) to productive (used) land, or from sub-marginal to supra-marginal land along spatiallyvarying background conditions [17]. Any change in force governing peoples' willingness to use land will lead to a transition between "marginal lands" and "normal lands" [51].

\subsection{Research Engagement and Priories}

Research and development (R\&D) and investments in areas with high agricultural potential cannot be neglected because these areas still provide much of the food needed to keep prices low, and to feed growing livestock and urban populations [44]. However, with the predicted trends in the population, extended $R \& D$ and greater public investment in some low-potential areas could offer a win-win strategy for addressing productivity and poverty problems; thus, investments in R\&D in marginal areas may actually give higher aggregate social returns to a nation than additional investments in high-potential and prime areas $[18,52]$.

Proper economic analysis of policy options and their impacts on small-scale and marginal farmers in resource-poor regions requires collecting appropriate data, methodology, and analytical tools for the economic valuation of environmental impacts. On this front, future research insulation must focus on collecting comprehensive and in-depth information on agricultural and resource management practices in marginal areas. This will enable future policy makers to make informed decisions and design policy instruments to address long-term issues related to productivity, environmental degradation, technological issues, food security, and poverty. Given this diversity of agroclimatic conditions in marginal areas and the need to tailor R\&D to local conditions to help define and identify marginality hotspots, poverty mapping as well as GIS techniques and spatially referenced data sets are proving useful in defining and mapping different types of less-favored areas at detailed scales in terms of the basic livelihood options available at community and household levels $[53,54]$.

Investing in targeted $R \& D$ to focus on the crops and traits that are important to the poor and the particular environmental limitations they face can diminish marginality and contribute to a widespread reduction of poverty [55]. Intensive research with a concentration on the poor in marginal environments may require a renewed research focus on some of the neglected and under-utilized crop and livestock species, particularly those that have the highest potential value for farmers' subsistence as sources of nutrition and food security. Conventional research methods that have proven successful in productive, favored areas may not be directly applicable under lagging and marginal production environments; therefore, future research should improve the local adoptability of neglected species with emphasis on targeted methods that could respond to the particular conditions of such biophysically and environmentally constrained areas. Agricultural research for 
marginal areas will need to generate developmental opportunities for targeted crop species that are central to the livelihoods and food security of the poor, and develop crop varieties with improved nutritional properties and better performance under low inputs and biotic and abiotic stresses.

Successive research documented several crop species that could thrive in marginal environments. Recently, there has been rising interest in introducing bioenergy production in marginal lands [56,57], and food crops such as quinoa and other halophytes that exhibit high tolerance to abiotic stresses typical of harsh climates [58,59]. In fact, numerous empirical research studies have corroborated competitive economic returns on investments in parts of India and China [44]. Quinoa was declared as a strategic crop by the Food and Agriculture Organization (FAO) due to its recognition as a stress-resistant crop with high nutritional value which is especially important for food security in marginal areas. However, little is known to the public and policy makers about the adoptability of these crops and their nutritional value. Other crops, such as halophytes including Salicornia, types of millets, and some forage crops, can be successfully adopted to marginal areas especially in dry areas where lands are degraded by salinity. Hence, further attention should be given to R\&D for marginal areas to focus on specialized breeding facilities to develop high-yielding, nutritious, and stress tolerant crop species for marginal conditions.

It is widely believed that the marginalized poor do not perceive that they benefit as much from environmental conservation efforts, while suffering the most from environmental degradation. The poor are often more vulnerable than others to the loss of ecosystem functions that restrict the availability of natural goods and the performance of services. This entails the direct dependence of the marginal poor upon ecosystem services. Thus the dynamic patterns of dependence on ecosystem services of the poor and their coping strategies require regionally specific and in-depth evaluation [60]. Soil degradation as the primary source of agricultural marginality poses a serious threat to diminishing soil functions and their ability to support ecosystem services essential for human well-being. In marginal areas, soil quality degradation has reportedly affected a significant amount of land and is expected to spread with climate change. Research and knowledge on soil quality management through soil amendment and customized fertilizer mixes are indispensable if we are intending to achieve the sustainable use and management of marginal lands. Marginal environments are mostly degraded because of unsustainable land uses; therefore, research to generate knowledge and information on sustainable land use, governance, and ecosystems must be prioritized.

Besides sustainable land management, water scarcity and quality remain major biophysical constraints that challenge sustainable production in marginal areas. To make informed decisions, policy makers need to know more about the type and the techniques of irrigation systems and practices that are best suited to marginal agricultural areas. In addition to water, water quality seems to be declining. Using treated water has become relatively common in agriculture; however, the research community will need to spend more on the quality as well as energy requirement for treated water. In areas where salinity is a major issue, leading to a low quality of soil and water, research must assess the economics of desalinization technologies and the appropriate crop intensification and rotation regimes under the context of biosaline agriculture.

Additional knowledge and research work are required to assess the suitability and viability of protected agriculture as a strategy to increase productivity per unit of land under marginal environmental conditions. Given the anticipated increase in population, per capita land is expected to decrease substantially, making land a binding and scarce resource. On this front, protected agriculture as a potential strategy to limit exposure to unfavorable biophysical stresses and extreme weather events can substantially increase yields, land productivity, and mitigate production risks. Moreover, protected agriculture technologies can ensure consumption smoothing over the year through off-season production, especially for subsistence smallholders who must subsist on their own production. 
Protected agriculture may also promote climate-smart and environmentally sustainable use of resources, as they are especially water-efficient.

\subsection{Outlook for Future Policies}

It has been established throughout this review that marginality is a multidimensional phenomenon driven by several interlinked environmental and socioeconomic factors. The well-established link between poverty and environment [11] requires long-term food-poverty-environment-focused development policies to address deep-rooted poverty and create an enabling environment for the extreme poor to become part of mainstream economies, while restoring the natural resource base in the presence of growing threats posed by climate change.

The tendencies of marginalized populations, particularly smallholders, to choose coping mechanisms and strategies with an immediate impact mainly geared towards risk mitigation have critical implications for guiding future policies. The poor in fragile and high-risk production environments are inclined to devise short-term strategies that are geared entirely to cope with risks trigged by climatic shocks and imperfect or failing market conditions, instead of investing in long-term solutions such as innovative technologies and production resources that are required to maximize production efficiencies. Sustaining agriculture and livelihoods in agriculturally marginal areas requires a significant shift in the current policy environment away from soothing short-term to more comprehensive policies that favor long-term viable investments to effectively respond to the growing food demand in the decades to come.

Innovative policies need to be different in focus and target. That is, future policies must evolve around a framework that is all-inclusive but context-specific. An integrated and holistic policy approach is necessary to advocate for collective action, engaging research institutions, policymakers, farmers and consumers, and other stakeholders to unlock the untapped potential of marginal lands. Deploying policy instruments targeting individual aspects of farming in isolation implies leaving too many "loose ends" and therefore is less likely to achieve the strategic developmental goals. Hence, an all-inclusive, integrated, and participatory policy approach is indispensable to engage all parties to align synergies and join forces in targeting productivity enhancement, whilst improving the fragile resource base in the face of severe climate change.

The information presented in the paper identifies the marginality hotspots representing areas that are extremely marginal (i.e., $1 \%$ of Sub-Saharan Africa, where five dimensions of marginality overlap) and areas that are relatively less marginal (i.e., where any two dimensions of marginality overlap). Ideally, geographical areas that are categorized as extremely marginal areas should be prioritized for future research and development, followed by other areas that are moderately marginal. Such areas will require immediate research and development support to effectively contribute to achieving SDG One and Two. Future policy interventions will vary in scope depending on the severity and type of factors leading to marginality within these hotspots; that is, context-specific approaches and R\&D actions will need to be designed to target dimensions peculiar to the individual marginality hotspot. Recent developments in land use and agricultural policies show significant progress towards sustaining agriculture production in marginal agriculture [5].

Public investments to promote more sustainable development pathways are warranted in marginal areas on both poverty and environmental grounds. The design and scope of potential interventions largely and essentially depends on the dimension of marginality being targeted and the local or regional economic context. Strategic options may vary from encouraging additional out-migration, promoting income diversification into nonfarm activities, increasing recurrent expenditure on safety net programs, supporting more intensive pathways of agricultural development, and introducing payment schemes for environmental services. Although non-agricultural options are perhaps more economically viable in transforming and industrializing economies with dynamic non-agricultural sectors, they are less viable in poor agrarian communities with stagnant economies $[53,61]$. 
Future interventions aiming to target agriculture in marginal areas need to take into account the local comparative advantages and the heterogenous nature of marginal environments [49]. Strategies for less-favored areas are likely to be more effective if they are linked to the development pathways that have comparative advantages in particular circumstances. For instance, small-scale water-saving irrigation technologies are likely to yield the highest returns with suitable soil conditions, since these can enable intensified and high-value crop production. On the contrary, road development is likely to have the highest returns in densely populated areas with good agricultural potential but limited market access, by enabling the marketing of high-value commodities and inputs. Investments in education and training are vital in low-potential areas with limited market access where immigration is likely to be an important element of people's livelihood strategies for the foreseeable future [18].

Tradeoffs between economic growth and poverty reduction objectives are more likely to arise in public investment decisions. Thus, another dimension of potential future policies is finding the right balance between income-generating and supportive activities (i.e., food security) and land use (e.g., land use for farming vs. urbanization). Since poverty and food security goals are strongly interlinked with environmental goals, future policy interventions need to identify and address where tradeoffs arise to ensure resources in both prime and marginal areas are sustainably used in achieving SDGs. Policy attempts to address individual goals in isolation will not only fail to target the rural poor, but will also put pressure on the natural resource base and lead to further dependence on exploiting environmental resources.

From a technological standpoint, major breakthroughs in productivity-enhancing agricultural technologies will be essential to reverse resource degradation and put marginal lands into optimal use. The Green Revolution may actually have created new sources of food insecurity in marginal areas by targeting high-potential areas and a handful of high-value and input-intensive crops grown there, mainly wheat, rice, and maize [62-64]. Policies for marginal environments must encourage the use of ecological processes instead of relying entirely on external inputs for crop production. Technologies that help reduce risks (by increasing tolerance to drought, pests, or frost, for example) and conserve and improve resources may be more effective than those that simply promote high yields in response to high levels of inputs [18]. Future technologies should account for and must be suited to the high degree of diversity in biophysical and socioeconomic conditions typical of marginal areas. The scope of future technological innovations must be different in several ways, so to be able to directly target the remaining poor (i.e., they should be cost-effective, productive, and sustainable).

The process of innovation and technological development for marginal agricultural environments must be based on a synergy between researchers and the marginalized farmers as the end users. Resource-poor farmers should not only be passive recipients of improved technologies but must play an active part in developing and adapting technological solutions to meet their own particular circumstances [47]. The proposed strategies for technological development should therefore be participatory and demand-driven, stimulating and building upon farmer innovations that are fit to local circumstances.

The importance of land tenure programs is reflected in the Sustainable Development Goals. As land holding size is substantially low in most parts of Sub-Saharan Africa, South Asia, and other agriculturally marginal areas, and will continue to decrease due to land fragmentation and land-use planning, governance and tenure policies are becoming very critical. Insecure land tenure rights and weak governance drive more marginalized and vulnerable people into being evicted from their farms, with women farmers being particularly at risk. As a result, rural unemployment is likely on the rise. Tenure reforms generate positive welfare effects for resource-poor farmers [65]. Improving secure access to land affects how people decide to use land resources and whether they invest in potential land improvement activities. More secure and equitable access to land can help empower disadvantaged groups (particularly women and marginalized populations) and ensure 
employment of the poor to their lands. Farm policies intended for marginal agriculture must therefore reinforce endogenous property rights systems to secure ownership rights over land and other resources.

Initiatives targeted at policy makers, researchers, and agribusinesses need to be aligned with capacity-development actions. They should seek to integrate knowledge generation with knowledge sharing in a manner that can effectively inform, and be informed by, action [66]. Farm households' decision-making in the context of risk and resilience challenges is often constrained by a lack of information on weather and market conditions. Many farmers in remotely marginal areas rely on an informal knowledge of local climates and weather patterns that has been acquired over decades or even centuries. The challenge posed for these households is that much of this knowledge base will be effectively destroyed as it is rendered irrelevant under the new climatology [67]. Policies for marginal areas should make efforts to encourage restoring knowledge base and risk-coping mechanisms including weather forecasts, early warning systems, extension systems, and drought monitoring and forecast models, especially for reaching disadvantaged and indigenous populations.

The impact of market reform policies in marginal areas has been mixed and often detrimental to the poor [49]. Since the development potential of marginal regions is often constrained by poor infrastructure and market access, the public sector must create an enabling and supportive policy environment to induce and incentivize investments in agricultural $\mathrm{R} \& \mathrm{D}$, rural infrastructure, and market access, to aid in transforming local subsistence production into market-led commercial production systems. Farmers, especially the smallholders, are poorly endowed with productive assets and liquidity constraints limit their access to modern inputs. Government policies at the national level must therefore invest to remedy market distortions, enhance the functions of local markets, and ensure access to long-term and affordable credit.

Coordinated public and private investments in the agriculture and food sectors must be a key dimension in future policies for agricultural and livelihood development in marginal areas. Attracting long-term private sector involvement will not only increase investments but will also promote resilience and efficiency in agri-food systems. The private sector could play an increasing role in creating "shared value" as an innovative business approach in which the long-term value and allocation of investments is shared between society and shareholders [68]. This means any involvement by the private sector in making business decisions on future plans should recognize social value, to ensure the needs and participation of the marginalized poor are reflected in business models undertaken by private sectors. The Nestle's dairy $\mathrm{n}$ India and Pakistan are a good example of creating such shared values, as they have invested to strengthen local dairy businesses, but also provided benefits to the wider society through infrastructure development and educational programs on production management, nutrition, and other aspects [68].

Given the increasing threat of climate change, the adaptation of climate-smart agricultural and regenerative agricultural practices must be placed on the top of the policy agenda for marginal areas to transform and reorient agricultural systems to effectively support development and ensure resilience against climate effects. Inter-disciplinary R\&D efforts will need to increasingly recognize the need to understand resilience against climate change and the sustainability of low-carbon economies. Poverty is evidently linked to environments in the context of marginal areas leading to the unbreakable poverty-environment traps [11]. Policies for restoring marginal areas must not be only poverty-focused but must also involve recommended conservation practices. The adoption of resource conservation technologies like zero tillage, residue application, permaculture, an appropriate use of fertilizer mixes, salt-tolerant varieties of crop, and promoting bio-saline agriculture practices will further enhance the potential of marginal lands to sequester carbon. In addition, the reclamation and improved management of degraded and salt-affected lands present great opportunity in marginal areas where salinity already happens to be affecting a large share of lands and will continue to spread at an increasing rate. Policy actions aimed at promoting resilience against climate change must address cross-cutting issues in all 
sectors. Tackling only the causes and impacts of environmental stresses facing agriculture production is a fragmented action that provides a partial solution only in the short run. In managing climate change, it is important to avoid considering its impacts in isolation from other processes of change, such as urbanization, land use, agricultural production, water resource management, and the use of other natural resources.

\section{Discussion and Conclusions}

In this paper, we discuss marginal lands and their role in food security, poverty elimination, and environmental sustainability. We undertake a systematic review of the multidimensional and complex nature of marginality and the factors that drive and characterize marginality to understand marginality in the context of agriculture. We draw a working definition for agricultural lands that are considered marginal in the context of a given agricultural economy, and use it to identify the extent of global and regional marginality hotspots. Understanding agricultural marginality and the identification of agriculturally marginal areas can play an important role in guiding future research and policy instruments. We also look into the historical policy environment to identify potential shortcomings and use them in developing a future policy framework to enhance productivity and restore the resource base in marginal areas. We analyze, consolidate, and summarize the findings of our literature review to identify research and policy priorities for marginal areas in Table 2.

Table 2. Synthesis and analysis of relevant literature on marginal areas with emphasis on priorities for research and future policy.

\begin{tabular}{|c|c|c|}
\hline Marginal Area Attributes & Key Points & Reference \\
\hline Background and geography & $\begin{array}{l}\text { Marginal areas make up } 15 \% \text { of the current } \\
\text { agricultural lands and } 21 \% \text { of total global land } \\
\text { resources } \\
\text { Nearly } 1 / 3 \text { of the world's rural population lives in } \\
\text { marginal areas; most are the poor of developing } \\
\text { nations } \\
\text { Marginality is not a static condition but is } \\
\text { influenced by interlinked economic, social, and } \\
\text { environmental factors } \\
\text { Variable climate and biodiversity of these areas } \\
\text { could be leveraged for productive farming }\end{array}$ & $\begin{array}{c}{[3,11,12,14,17,18,} \\
23,35,38- \\
41,50,51]\end{array}$ \\
\hline $\begin{array}{l}\text { Importance for future food } \\
\text { and environmental security }\end{array}$ & $\begin{array}{l}\text { Diminishing returns of highly productive lands } \\
\text { due to erosion, salinization, and waterlogging } \\
\text { Marginal agriculture is the main outlet for the } \\
\text { majority of the world's poor and will play an } \\
\text { increasingly important role } \\
\text { - Social returns to investment may be higher in } \\
\text { marginal areas than more investment in } \\
\text { prime areas }\end{array}$ & $\begin{array}{c}{[3,10,14,29,43,44,} \\
48,52,69,70]\end{array}$ \\
\hline $\begin{array}{l}\text { Historical policies: } \\
\text { challenges and limitations }\end{array}$ & 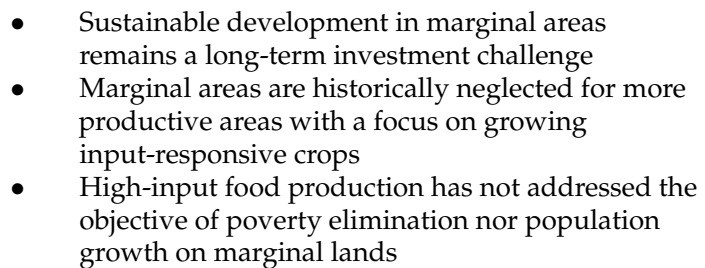 & {$[8,14,44,46-49,53]$} \\
\hline
\end{tabular}


Table 2. Cont.

\begin{tabular}{|c|c|c|}
\hline Marginal Area Attributes & Key Points & Reference \\
\hline $\begin{array}{l}\text { Roadmap to research } \\
\text { engagement in } \\
\text { marginal areas }\end{array}$ & $\begin{array}{l}\text { Marginal lands are essential for producing enough } \\
\text { food to feed growing populations and for keeping } \\
\text { food prices affordable } \\
\text { Investment in marginal areas can be a win-win for } \\
\text { addressing productivity and global poverty } \\
\text { - Conventional research may not apply to marginal } \\
\text { lands. Future research should focus on crop traits } \\
\text { for the poor } \\
\text { - Socioeconomic valuation of environmental impacts } \\
\text { in and poverty mapping of marginal lands required }\end{array}$ & $\begin{array}{c}{[9,18,44,45,48,56,} \\
57,69]\end{array}$ \\
\hline $\begin{array}{l}\text { Outlook and policy options } \\
\text { to put marginal lands to } \\
\text { optimal use }\end{array}$ & $\begin{array}{l}\text { Public investments need to be all-inclusive but } \\
\text { context-specific to consider comparative } \\
\text { advantages of marginal areas } \\
\text { Future interventions will largely depend on the } \\
\text { dimension of marginality being targeted } \\
\text { - } \quad \text { Policies to focus on both poverty and climate } \\
\text { resilience } \\
\text { Policies should seek to integrate data generation } \\
\text { and knowledge sharing } \\
\text { Both public and private investment needed, with } \\
\text { increasing private sector role in creating shared } \\
\text { value } \\
\text { Land tenure reform may be needed to insure more } \\
\text { secure and equitable land access and } \\
\text { property rights }\end{array}$ & $\begin{array}{c}{[11,18,49,51,55} \\
65,69,70]\end{array}$ \\
\hline
\end{tabular}

Previous research shows that marginal lands make up about $21 \%$ (2.74 billion ha) of total land resources (13.5 billion ha). However, about 1558 million ha of the total land resources are used for agriculture, out of which about 224-300 million ha are classified as agriculturally marginal areas. From a demographic perspective, nearly 1.75 billion people worldwide (equivalent to $38 \%$ of the rural population) live on remote less-favored and marginal agricultural lands and nearly 1.6 (out of 1.75) billion people inhabit marginal areas based in developing countries, the majority of whom are the world's extreme poor. Despite the constraint exercised on the productivity of marginal areas by biophysical and economic factors, recent research has established that marginality is not a static and permanent condition. With appropriate policies and interventions in place, the condition of marginality is reversable; indeed, the heterogenous conditions typical of marginal areas represent a comparative advantage that could be utilized for the benefit of those that are extremely poor, who have been left behind for decades.

From the comprehensive literature review, we draw the conclusion that the conventional policy approaches towards marginal agriculture have been conducive to favorable areas (specific to input-responsive crops only), neglecting marginal areas. As a result, the extremely poor in marginal environments have been overlooked and did not benefit much from the technological progress. Despite the overall decline in global poverty, poverty is on the rise and food insecurity is widely prevalent in marginal areas. For the world to achieve sustainable development goals related to poverty, food security, and the environment, marginal lands need to be increasingly recognized in future policy frameworks.

Future policies to address the food-poverty-environment nexus within marginal environments must be different in their focus and target. That is, future policies must evolve around a framework that is all-inclusive but context-specific. Agricultural and other public investments should be prioritized geographically in accordance with the characteristics of marginality hotspots. Policy instruments should encourage long-term solutions to enhance productivity through regenerative production systems and preserve the environmental resource-base. To this end, the process of innovation and technological development for marginal agricultural environments must be participatory and demand-driven, stimulating and building upon farmer innovations that are fit to local circumstances. Initiatives targeted 
at policy makers, researchers, and agribusinesses need to be aligned with capacity development actions to restore the knowledge base in marginal and indigenous communities.

Author Contributions: Conceptualization, H.A., S.T. and I.E.; methodology, H.A. and S.T.; formal analysis, H.A.; writing —original draft preparation, H.A.; writing-review and editing, S.T. and I.E. All authors have read and agreed to the published version of the manuscript.

Funding: This research received no external funding.

Institutional Review Board Statement: Not applicable.

Informed Consent Statement: Not applicable.

Conflicts of Interest: The authors declare no conflict of interest.

\section{References}

1. Sandhu, H. Bottom-Up Transformation of Agriculture and Food Systems. Sustainability 2021, 13, 2171. [CrossRef]

2. Godfray, H.C.J.; Beddington, J.R.; Crute, I.R.; Haddad, L.; Lawrence, D.; Muir, J.F.; Pretty, J.; Robinson, S.; Thomas, S.M.; Toulmin, C. Food Security: The Challenge of Feeding 9 Billion People. Science 2010, 327, 812-818. [CrossRef]

3. Alexandratos, N.; Bruinsma, J. World Agriculture Towards 2030/2050, The 2012 Revision; ESA Working Paper No. 12-03; Food and Agriculture Organization of the United Nations: Quebec, QC, Canada, 2012.

4. Bommarco, R.; Kleijn, D.; Potts, S.G. Ecological Intensification: Harnessing Ecosystem Services for Food Security-ScienceDirect. Trends Ecol. Evol. 2013, 28, 230-238. [CrossRef]

5. Strijker, D. Marginal Lands in Europe-Causes of Decline. Basic Appl. Ecol. 2005, 6, 99-106. [CrossRef]

6. Barbier, E.B.; Bugas, J.S. Structural Change, Marginal Land and Economic Development in Latin America and the Caribbean. Lat. Am. Econ. Rev. 2014, 23, 3. [CrossRef]

7. McKenzie, F.C.; Williams, J. Sustainable Food Production: Constraints, Challenges and Choices by 2050. Food Secur. 2015, 7, 221-233. [CrossRef]

8. Byerlee, D.; Husain, T. Agricultural Research Strategies for Favoured and Marginal Areas: The Experience of Farming Systems Research in Pakistan. Exp. Agric. 1993, 29, 155-171. [CrossRef]

9. Lantican, M.A.; Pingali, P.L.; Rajaram, S. Is Research on Marginal Lands Catching up? The Case of Unfavourable Wheat Growing Environments. Agric. Econ. 2003, 29, 353-361. [CrossRef]

10. Barbier, E.B. Poverty, Development, and Environment. Environ. Dev. Econ. 2010, 15, 635-660. [CrossRef]

11. Barbier, E.B.; Hochard, J.P. Poverty-Environment Traps. Environ. Resour. Econ. 2019. [CrossRef]

12. Barbier, E.B.; Hochard, J.P. Does Land Degradation Increase Poverty in Developing Countries? PLoS ONE 2016, 11, e0152973. [CrossRef]

13. Gray, L.C.; Moseley, W.G. A Geographical Perspective on Poverty-Environment Interactions. Geogr. J. 2005, 171, 9-23. [CrossRef]

14. Gurung, G.S.; Kollmair, M. Marginality: Concepts and Their Limitations; IP6 Working Paper No. 4; University of Zurich: Zürich, Switzerland, 2005.

15. Lewis, S.; Kelly, M. Mapping the Potential for Biofuel Production on Marginal Lands: Differences in Definitions, Data and Models across Scales. ISPRS Int. J. Geo-Inf. 2014, 3, 430-459. [CrossRef]

16. Soldatos, P. Economic Aspects of Bioenergy Production from Perennial Grasses in Marginal Lands of South Europe. Bioenerg. Res. 2015, 8, 1562-1573. [CrossRef]

17. Sallustio, L.; Pettenella, D.; Merlini, P.; Romano, R.; Salvati, L.; Marchetti, M.; Corona, P. Assessing the Economic Marginality of Agricultural Lands in Italy to Support Land Use Planning. Land Use Policy 2018, 76, 526-534. [CrossRef]

18. Pender, E.J.; Hazell, P. Promoting Sustainable Development in Less-Favored Areas. Int. Food Policy Res. Inst. 2000, 1-20. Available online: https:/ / www.ifpri.org/publication/promoting-sustainable-development-less-favored-areas (accessed on 20 June 2021).

19. Gatzweiler, F.W.; von Braun, J. Innovation for Marginalized Smallholder Farmers and Development: An Overview and Implications for Policy and Research. In Technological and Institutional Innovations for Marginalized Smallholders in Agricultural Development; Gatzweiler, F.W., von Braun, J., Eds.; Springer: Cham, Switzerland, 2016; pp. 1-22, ISBN 978-3-319-25718-1.

20. FAO; IFAD; UNICEF; WFP; WHO. The State of Food Security and Nutrition in the World 2017. Building Resilience for Peace and Food Security; FAO: Rome, Italy, 2017.

21. FAO; IFAD; UNICEF; WFP; WHO. The State of Food Security and Nutrition in the World 2018. Building Climate Resilience for Food Security and Nutrition; FAO: Rome, Italy, 2018; Licence: CC BY-NC-SA 3.0 IGO.

22. FAO; IFAD; UNICEF; WFP; WHO. The State of Food Security and Nutrition in the World 2019. Safeguarding against Economic Slowdowns and Downturns; FAO: Rome, Italy, 2019; Licence: CC BY-NC-SA 3.0 IGO.

23. Gatzweiler, F.W.; Baumüller, H.; Husmann, C.; von Braun, J. Marginality: Addressing the Root Causes of Extreme Poverty. SSRN J. 2011. [CrossRef]

24. Lal, R. Soil Carbon Sequestration Impacts on Global Climate Change and Food Security. Science 2004, 304, 1623-1627. [CrossRef]

25. Tilman, D.; Balzer, C.; Hill, J.; Befort, B.L. Global Food Demand and the Sustainable Intensification of Agriculture. Proc. Natl. Acad. Sci. USA 2011, 108, 20260-20264. [CrossRef] 
26. Fischer, T.; Beyerlee, D.; Edmeades, G. Crop Yields and Global Food Security: Will Yield Increase Continue to Feed the World?; Canberra: ACIAR Monograph No. 158; Australian Centre for International Agricultural Research: Canberra, Australia, 2015.

27. Peterson, G.M.; Galbraith, J.K. The Concept of Marginal Land. J. Farm Econ. 1932, 14, 295. [CrossRef]

28. Mehretu, A.; Pigozzi, B.W.; Sommers, L.M. Concepts in Social and Spatial Marginality. Geografiska Ann. 2000, 82, 89-101. [CrossRef]

29. Pulighe, G.; Bonati, G.; Colangeli, M.; Morese, M.M.; Traverso, L.; Lupia, F.; Khawaja, C.; Janssen, R.; Fava, F. Ongoing and Emerging Issues for Sustainable Bioenergy Production on Marginal Lands in the Mediterranean Regions. Renew. Sustain. Energy Rev. 2019, 103, 58-70. [CrossRef]

30. FAO and UNEP A Decision Support. Tool for Sustainable Bioenergy; UN Energy Publication: New York, NY, USA, 2010; p. 50. ISBN 978-92-5-106638-6.

31. Dauber, J.; Brown, C.; Fernando, A.L.; Finnan, J.; Krasuska, E.; Ponitka, J.; Styles, D.; Thrän, D.; Van Groenigen, K.J.; Weih, M.; et al. Bioenergy from "Surplus" Land: Environmental and Socio-Economic Implications. BioRisk 2012, 7, 5. [CrossRef]

32. Deal, J. The Relationship Between Economically and Environmentally Marginal Land. In Proceedings of the Selected Paper Prepared for Presentation at the American Agricultural Economics Association Annual Meeting, Long Beach, CA, USA, 23-26 July 2006.

33. Baxter, R.E.; Calvert, K.E. Estimating Available Abandoned Cropland in the United States: Possibilities for Energy Crop Production. Ann. Am. Assoc. Geogr. 2017, 107, 1162-1178. [CrossRef]

34. World Bank. World Development Report 2008: Agriculture for Development; The World Bank: Washington, DC, USA, 2008.

35. Kang, S.; Post, W.M.; Nichols, J.A.; Wang, D.; West, T.O.; Bandaru, V.; Izaurralde, R.C. Marginal Lands: Concept, Assessment and Management. J. Agric. Sci. 2013, 5, 129. [CrossRef]

36. Worldwatch Institute. Biofuels for Transport: Global Potential and Implications for Sustainable Energy and Agriculture, Prepared by Worldwatch Institute for the German Ministry of Food, Agriculture and Consumer Protection (BMELV) in Coordination with the German Agency for Technical Cooperation (GTZ) and the German Agency of Renewable Resources (FNR); Earthscan: London, UK, 2007; ISBN 978-1-84407-422-8.

37. Campbell, J.E.; Lobell, D.B.; Genova, R.C.; Field, C.B. The Global Potential of Bioenergy on Abandoned Agriculture Lands. Environ. Sci. Technol. 2008, 42, 5791-5794. [CrossRef]

38. CGAIR/TAC CGIAR Research Priorities for Marginal Lands; CGIAR (Consultative Group on International Agricultural Research); Technical Advisory Committee (TAC): Washington, DC, USA, 2000. Available online: https://cgspace.cgiar.org/handle/10947/ 332 (accessed on 1 June 2021).

39. FAO. The State of the World's Land and Water Resources for Food and Agriculture (SOLAW)—Managing Systems at Risk; Earthscan: London, UK, 2011; ISBN 978-0-203-14283-7.

40. Fischer, G.; Hizsnyik, E.; Prieler, S.; Wiberg, D. Scarcity and Abundance of Land Resources: Competing Uses and the Shrinking Land Resource Base; SOLAW Background Thematic Report TR02; FAO: Rome, Italy, 2010; p. 58. Available online: http:// pure.iiasa.ac at/id/eprint/13290/ (accessed on 12 February 2021).

41. Fischer, G.; Nachtergaele, F.O.; Prieler, S.; Teixeira, E.; Tóth, G.; Van Velthuizen, H.; Verelst, L.; Wiberg, D. Global Agro-Ecological Zones (GAEZ v3. 0)—Model Documentation; IIASA: Laxenburg, Austria; FAO: Rome, Italy, 2012. Available online: http:/ / pure. iiasa.ac.at/id/eprint/13290/1/GAEZ_Model_Documentation.pdf (accessed on 20 June 2021).

42. Graw, V.; Husmann, C. Mapping Marginality Hotspots. In Marginality; von Braun, J., Gatzweiler, F.W., Eds.; Springer: Dordrecht, The Netherlands, 2014; pp. 69-83, ISBN 978-94-007-7060-7.

43. Mogues, T.; Yu, B.; Fan, S.; McBride, L. The Impacts of Public Investment in and for Agriculture, Synthesis of the Existing Evidence; ESA Working Paper No. 1217; Food and Agriculture Organization of the United Nations: Rome, Italy, 2012.

44. Fan, S.; Hazell, P. Returns to Public Investments in the Less-Favored Areas of India and China. Am. J. Agric. Econ. 2001, 83, 1217-1222. [CrossRef]

45. Adhikari, B. Poverty Reduction through Promoting Alternative Livelihoods: Implications for Marginal Drylands. J. Int. Dev. 2013, 25, 947-967. [CrossRef]

46. Pingali, P.L. Green Revolution: Impacts, Limits, and the Path Ahead. Proc. Natl. Acad. Sci. USA 2012, 109, 12302-12308. [CrossRef]

47. Reece, J.D.; Sumberg, J. More Clients, Less Resources: Toward a New Conceptual Framework for Agricultural Research in Marginal Areas. Technovation 2003, 23, 409-421. [CrossRef]

48. Scherr, S.J.; Hazell, P.B.R. Sustainable Agricultural Development Strategies in Fragile Lands; EPTD Discussion Paper No. 1; International Food Policy Research Institute: Washington, DC, USA, 1994.

49. Kuyvenhoven, A.; Pender, J.; Ruben, R. Development Strategies for Less-Favoured Areas. Food Policy 2004, 29, $295-302$.

50. Lipper, L.; Pingali, P.; Zurek, M. Less-favoured areas: Looking beyond agriculture towards ecosystem services. In Sustainable Poverty Reduction in Less-Favoured Areas; The Food and Agriculture Organization of the United Nations: Wallingford, UK, 2007; pp. 442-460, ISBN 978-1-84593-277-0.

51. Jiang, W.; Jacobson, M. The Conceptual Discussoin of Economically Marginal Lands for Planting Energy Crops. In Proceedings of the Inaugural Symposium of the International Society of Forest Resource Economci. 2014. Available online: https: / /www.isfre. msstate.edu/docs /2014_proceedings.pdf\#page=66 (accessed on 12 June 2021).

52. Fan, S.; Hazell, P. Should Developing Countries Invest More in Less-Favoured Areas? An Empirical Analysis of Rural India. Econ. Political Wkly. 2000, 35, 1455-1464. 
53. Hazell, P.; Ruben, R.; Kuyvenhoven, A.; Jansen, H. Development Strategies for Less-Favored Areas. In Development Economics between Markets and Institutions: Incentives for Growth, Food Security and Sustainable Use of the Environment, Mansholt Publication Series_-Volume 4; Wageningen Academic Publishers: Wageningen, The Netherlands, 2007.

54. Ruben, R.; Pender, J. Rural Diversity and Heterogeneity in Less-Favoured Areas: The Quest for Policy Targeting. Food Policy 2004, 29, 303-320. [CrossRef]

55. Gatzweiler, F.W.; Baumüller, H. Marginality-A Framework for Analyzing Causal Complexities of Poverty. In Marginality; Springer: Dordrecht, The Netherlands, 2014; pp. 27-40, ISBN 978-94-007-7060-7.

56. Nalepa, R.A.; Bauer, D.M. Marginal Lands: The Role of Remote Sensing in Constructing Landscapes for Agrofuel Development. J. Peasant Stud. 2012, 39, 403-422. [CrossRef]

57. Richards, B.K.; Stoof, C.R.; Cary, I.J.; Woodbury, P.B. Reporting on Marginal Lands for Bioenergy Feedstock Production: A Modest Proposal. Bioenerg. Res. 2014, 7, 1060-1062. [CrossRef]

58. López-Arredondo, D.; González-Morales, S.I.; Bello-Bello, E.; Alejo-Jacuinde, G.; Herrera, L. Engineering Food Crops to Grow in Harsh Environments. F1000Research 2015, 4, 651. [CrossRef]

59. Choukr-Allah, R.; Rao, N.K.; Hirich, A.; Shahid, M.; Alshankiti, A.; Toderich, K.; Gill, S.; Butt, K.U.R. Quinoa for Marginal Environments: Toward Future Food and Nutritional Security in MENA and Central Asia Regions. Front. Plant Sci. 2016, 7. [CrossRef]

60. Kumar, P.; Yashiro, M. The Marginal Poor and Their Dependence on Ecosystem Services: Evidence from South Asia and SubSaharan Africa. In Marginality Addressing the Nexus of Poverty, Exclusion and Ecology. In Marginality; Springer: Dordrecht, The Netherlands, 2014; pp. 169-180, ISBN 978-94-007-7060-7.

61. Haggblade, S.; Hazell, P.; Reardon, T. Strategies for Stimulating Poverty-Alleviating Growth in the Rural Nonfarm Land Economy in Developing Countries. Environment and Production Technology; Discussion Paper No. 92; International Food Policy Research Institute: Washington, DC, USA, 2002.

62. Pearse, A. Seeds of Plenty Seeds of Want: Social and Economic Implications of the Green Revolution; Oxford University Press: New York, NY, USA, 1990.

63. Shiva, V. The Violence of the Green Revolution: Third World Agriculture, Ecology and Politics; Third World Network: Penang, Malaysia, 1991.

64. Pingali, P.L.; Hossain, M.; Gerpacio, R.V. Asian Rice Bowls: The Returning Crisis; CAB International: Wallinford, UK, 1997.

65. Ruben, R.; Kuiper, M.H.; Pender, J. Searching Development Strategies for Less-Favoured Areas. NJAS Wagening. J. Life Sci. 2006, 53, 319-342. [CrossRef]

66. Virji, H. Capacity Building to Support Knowledge Systems for Resilient Development-Approaches, Actions, and Needs. Curr. Opin. Environ. Sustain. 2012, 4, 115-121. [CrossRef]

67. Quiggin, J.; Horowitz, J. Costs of Adjustment to Climate Change. Aust. J. Agric. Resour. Econ. 2003, 47, 429-446. [CrossRef]

68. Christiansen, N. Business Initiatives That Overcome Rural Poverty and Marginality Through Creating Shared Value. In Marginality; von Braun, J., Gatzweiler, F.W., Eds.; Springer: Dordrecht, The Netherlands, 2014; pp. 353-364, ISBN 978-94-007-7060-7.

69. Springmann, M.; Clark, M.; Mason-D'Croz, D.; Wiebe, K.; Bodirsky, B.L.; Lassaletta, L.; de Vries, W.; Vermeulen, S.J.; Herrero, M.; Carlson, K.M. Options for Keeping the Food System within Environmental Limits. Nature 2018, 562, 519. [CrossRef] [PubMed]

70. Willett, W.; Rockström, J.; Loken, B.; Springmann, M.; Lang, T.; Vermeulen, S.; Garnett, T.; Tilman, D.; DeClerck, F.; Wood, A.; et al. Food in the Anthropocene: The EAT-Lancet Commission on Healthy Diets from Sustainable Food Systems. Lancet 2019, 393, 447-492. [CrossRef] 